\title{
Materialno-biologiczny wymiar obrazu Bożego w człowieku
}

\author{
(Material-biological dimension \\ of the image of God in man)
}

\section{ROBERT J. WOŹNIAK}

Wydział Teologiczny Uniwersytetu Papieskiego Jana Pawła II w Krakowie robert.wozniak@upip2.edu.pl

Streszczenie. W artykule przedstawiono zarys teologii imago Dei w perspektywie naukowej wizji człowieka. Dzisiaj taka wizja jest określona istotnie przez szczegółowe nauki o człowieku, jak neurologia i kognitywistyka. Twierdzą one, że racjonalność i wolność człowieka są osadzone w konkretnych strukturach biologicznych i mogą być wyjaśnione na ich podstawie.Z takiej perspektywy imago Dei, który klasyczna tradycja teologiczna wiązała z ludzką racjonalnością i wolnością, nie powinien być rozumiany jako rzeczywistość czysto duchowa. Nowe metody i dane nauk stawiają teologię przed koniecznością przemyślenia tradycyjnego pojęcia obrazu w kierunku szerszej artykulacji jego materialnej struktury i natury. Człowiek, jako istota cielesna, jest obrazem Boga. Takie stwierdzenie nie oznacza konieczności przyjęcia jakiegokolwiek niewłaściwego redukcjonizmu czy ontologicznego monizmu i nie może być traktowane jako intelektualne uzasadnienia radykalnego naturalizmu właściwego niektórym 'nowym ateizmom?. Artykuł pokazuje jak to twierdzenie można obronić z zachowaniem punktu widzenia klasycznej doktryny stworzenia właściwej dla chrześcijańskiej teologii.

Stowa klucze: imago Dei; teologia; materialność; redukcjonizm; nauki ścisłe.

Abstract. The article presents the theology of imago Dei in perspective of scientific vision of human being. Today such vision is determined in the very special way by increasing influence of neurology and cognitive sciences. They claim that rationality and freedom of human being is grounded in the specific biological structures and can 
be explained by it. From such perspective imago Dei, which was defined by theological tradition as linked to human rationality and freedom, should not be understood as a merely spiritual dimension. New approaches and data of sciences introduce the necessity of rethinking traditional idea of the image toward broader articulation of its material character and nature. Human being, as a corporeal being, is the image of God. Such statement does not imply any kind of inappropriate reductionism or ontological monism and cannot be taken as an intellectual justification of radical naturalism. The article shows how this claim can be proved from the point of view of classical Christian doctrine of creation.

Keywords: imago Dei; theology; materiality; reductionism; science.

Koncepcja stworzenia człowieka na obraz i podobieństwo stanowi fundament chrześcijańskiej antropologii. Zapewne ta jej fundamentalność sprawia, że w ciągu wieków tradycji teologicznej została ona opracowana w takiej mierze jak rzadko który jej temat. Refleksje na temat istoty i znaczenia imago Dei odnajdziemy już u wczesnych teologów, a poszerzenie i ubogacenie ich doktryny będzie stanowiło jeden z uprzywilejowanych punktów teologicznego myślenia w średniowieczu i całej nowożytności.

Dzisiejsza sytuacja i stan wiedzy o człowieku proponują antropologii teologicznej konkretne intuicje mogące zaoferować twórczy powrót do starej i szlachetnej tradycji ${ }^{1}$. Mam tu na myśli przede wszystkim szybki rozwój biologii, neurologii i kognitywistyki (por. Newberg 2010). Nauki te, wewnątrz ich własnych granic metodologicznych i przedmiotowych, starają się wyjaśnić fenomeny związane z genezą i funkcjonowaniem umysłu oraz powiązanych z nim czynności duchowych człowieka². Teologia nie jest

1 W interesującym nas temacie istotny przyczynek do debaty stanowi zbiorowa publikacja: Souvignier, Lüke 2008.

2 Zob. definicję kognitywistyki zaproponowaną w: Hohol 2013, 20: „Przez kognitywistykę sensu largo rozumiem multidyscyplinarne przedsięwzięcie obejmujące wachlarz różnorodnych dziedzin, takich jak: filozofia, logika, psychologia, neuroscience (w tym także neuronauka poznawcza), nauki komputerowe (computer science), lingwistyka (zarówno generatywistyczna, jak i kognitywna), fizyka (w szczególności mechanika kwantowa), nauki ewolucyjne oraz antropologia fizyczna i kulturowa. Wykorzystanie wszystkich tych dyscyplin jest podporządkowane wspólnemu - ale zarazem bardzo ogólnemu - celowi, jakim jest lepsze zrozumienie procesów poznawczych człowieka oraz innych zwierząt. Mówiąc jeszcze ogólniej: kognitywistyka próbuje zrozumieć, jak działa umysł”. 
kompetentna do wypowiadania się, co do ich przedmiotu badań. Niemniej jednak sama jest nimi zainteresowana i to nie tylko z tego powodu, żeby bronić konturów własnej ortodoksji w obliczu pojawiających się od czasu do czasu redukcjonizmów i uproszczeń głoszonych przez nieliczną grupę naukowców, lecz także żeby neutralne wyniki tych badań mogły przyczynić się do wypracowania nowych wizji, ominięcia zbyt uproszczonych poglądów teologicznych oraz ciągłego pogłębiania relacji nauki i wiary.

Przedmiotem niniejszego przedłożenia jest możliwość ujęcia idei imago Dei jako rzeczywistości o materialnym ${ }^{3}$ substracie. Jego tematyka wiąże się z materialnym wymiarem ludzkiego bycia na obraz Boga. Czemu taki przedmiot badań? Bez wchodzenia w kompetencje kognitywistki i biologii chodzi o pokazanie możliwego pomostu, jaki można by zbudować między tymi naukami a samą teologią. W tym względzie podkreślenie materialnej struktury imago może stanowić punkt wyjścia szerszej debaty mającej na celu opracowanie bardziej szczegółowych zagadnień w dialogu między współczesną wizją antropologiczną, zdominowaną przez nauki ścisłe, a teologią. Zamiarem artykułu nie jest ani prezentacja, ani krytyczna ocena danych nauk ścisłych, lecz wskazanie na istniejący punkt wspólny między nimi a teologią w kwestii ujęcia natury człowieka. Ten punkt wspólny można, moim zdaniem, odnaleźć w tym, że zarówno nauki, jak i sama teologia odkrywają dzisiaj istotną wagę materialnego wymiaru bycia człowiekiem.

Ten materialny charakter boskiego imago w człowieku zwyczajowo nie bywa wystarczająco eksponowany. Niniejsza publikacja jest próbą jego przybliżenia. Artykuł będzie podzielony na kilka części. W pierwszej z nich przedstawię typologię klasycznych ujęć natury boskiego obrazu. Na jej tle zostanie, w części drugiej, rozważona kwestia materialności interesującego nas imago.

3 W niniejszym przyczynku używam pojęcia „materia” świadomy jego niejednoznaczności i niecałkowitej adekwatności, szczególnie z perspektywy nauk ścisłych. Na temat znaczenia pojęcia materii na styku paradygmatów filozofii i nauk zob., Heller, Pabian 2014, 81-90. 


\section{Typologia obrazu Bożego w człowieku}

Wielość wątków tradycji teologicznego myślenia o boskim obrazie domaga się typologizacji. Próbę systematyzacji podjął niedawno Marc Cortez (2010). Amerykański teolog porządkuje różne teologie imago w cztery główne grupy ideowe odpowiadające ujęciu: strukturalnemu (A'), funkcjonalnemu (B'), relacyjnemu (C') oraz wieloaspektowemu (D').

A'. Strukturalne ujęcia obrazu podkreślają jego związek z istotą bycia osobą ludzką, z czymś, co sprawia, że człowiek jest człowiekiem, z czymś, co wyróżnia go spośród innych bytów. W niektórych wersjach strukturalnego ujęcia imago utożsamia się go z pewnymi zdolnościami albo całymi grupami zdolności, które decydują o byciu człowiekiem. Taka kryteriologia podyktowana jest podwójnym argumentem. Po pierwsze, teolodzy zdają sobie sprawę, że imago jest wyjątkową i ekskluzywną cechą bycia człowiekiem. Żadne inne ze stworzeń nie jest sensu stricto obrazem Boga. Po drugie, boski obraz oznacza pewną referencję porządku stworzonego względem porządku bycia Boga. Obraz Boga czyni widzialnymi w świecie pewne wymiary boskiego bycia. Biorąc pod uwagę obydwa argumenty, imago musi oznaczać coś specyficznie ludzkiego z jednej strony, z drugiej zaś pewną własność, która przynależy również Bogu, a w człowieku stanowi odzwierciedlenie boskiego porządku bycia. Naturalnymi kandydatami spełniającymi wspomniane kryteria są racjonalność, wolność, zdolność decydowania o sobie, autotranscendencja, zdolność myślenia symbolicznego.

B'. Funkcjonalna koncepcja imago akcentuje nie tyle pewne statyczne wymiary ludzkiego bycia, jak te, które wspomniano powyżej, ile bardziej skupia się na obrazie jako osadzonym w ludzkim działaniu. Imago Dei oznacza funkcję człowieka bardziej niż jego istotę lub układ zdolności jemu tylko właściwych: jest on „bardziej czymś, co ludzie robia, niż czymś, czym ludzie sq̨" (Cortez 2010, 21). Ujęty w kategoriach działania boski obraz w człowieku oznacza powołanie człowieka do reprezentacji stwórczej i porządkującej mocy Boga 
wobec stworzenia. Panowanie człowieka nad stworzeniem jest samą istotą ludzkiego bycia na obraz Boga. Cortez stwierdza, że ten sposób pojęciowania natury obrazu zasadza się o wiele bardziej na przesłankach biblijnych niż model strukturalny.

C'.Zgodnie z następnym ujęciem imago Dei dotyczy relacyjnego charakteru ludzkiego bycia. Człowiek jest istotą relacyjną, jego sposób bycia określony jest przez sieć relacji, odniesień. Ludzkie bycie jest byciem-z, byciem-dla, byciem-ku. Te wielorakie relacje odnoszą człowieka do Boga, do drugiego człowieka oraz do świata. Nie ulega wątpliwości, że relacyjna koncepcja obrazu zbudowana jest na bazie wątków zaczerpniętych z klasycznej teologii trynitarnej, która co najmniej od IV wieku systematycznie wiązała swoją refleksję nad objawioną tajemnicą Boga z pojęciem relacji. Relacyjność ludzkiego bycia stanowi obraz boskiego życia wewnętrznego. Fundamentalna relacyjność człowieka znajduje swoje źródło w stworzeniu człowieka rozróżnionego płciowo: zasadnicza różnica między mężczyzną a kobietą, pozostając w ramach przeczucia jedności rodzaju ludzkiego, stanowi pierwotny i analogiczny odblask relacyjności, która zakorzeniona jest w trynitarnej immanencji. W tym kontekście Cortez cytuje Bartha, którego zdaniem „człowiek jest stworzony przez Boga w korespondencji z relacją i rozróżnieniem w samym Bogu”.

D'.Czwarty typ rozumienia istoty boskiego obrazu w człowieku, zwany prze Corteza wieloaspektowym (multifaceted), charakteryzuje podejście, które wyróżnia się twierdzeniem, że imago jest koncepcją wielowątkową, która nie może być sprowadzona do jednej jedynej grupy znaczeniowej. Według nich obraz Boży to koncepcja złożona, domagająca się wyjścia poza ograniczenia właściwe wspomnianym powyżej podejściom strukturalnym, funkcjonalnym i relacyjnym. Jedynie synteza wszystkich typów teologicznych ujęć obrazu pozwala na adekwatne zbliżenia się do pełni jego znaczenia. Istotnym zadaniem i aspiracją tego ujęcia jest propozycja syntezy poprzednich ujęć, w szczególności funkcjonalnego i relacyjnego. Cortez proponuje osiągnąć ją poprzez wyakcentowanie pojęcia obecności 
Boga. Ostatecznie definiuje on boski obraz jako: „God manifesting his personal presence in creation through his covenantal relationships with human persons, whom he has constituted as personal beings to serve as his representatives in creation and to whom he remains faithful despite their sinful rejection of him" (Cortez 2010, 37). Z perspektywy tej definicji teologia obrazu nie jest próbą zdefiniowania człowieka i jego istoty, a raczej jedynie ustawieniem go we właściwym mu teologicznym i narracyjnym kontekście. Doktryna stworzenia na boski obraz określa podstawowe miejsce hermeneutyczne chrześcijańskiej antropologii.

Wspomniany kontekst pozwala Cortezowi na wyliczenie głównych implikacji antropologicznych wspomnianego ujęcia. Należą do nich następujące prawdy: Jezus Chrystus jest Objawieniem prawdziwego człowieczeństwa, ludzka osoba jest częścią stworzenia, jak i jego wyjątkowym momentem, człowiek jest tajemnicą, istota ludzka jest bytem relacyjnym, odpowiedzialnym, ucieleśnionym (emboded) i upadłym (broken) (Cortez 2010, 40).

\section{Ucieleśniony obraz Boga?}

Zauważmy, że jednym z punktów powyższej listy teologicznych implikacji wynikających z koncepcji obrazu jest, zdaniem Corteza, ucieleśnienie. Obraz boski w człowieku jest obrazem ucieleśnionym. Pojęcie ucieleśnienia służy oczywiście do wyakcentowania czegoś bardziej ogólnego niż sam fakt, że człowiek posiada ciało. Chodzi w nim o odsłonięcie istotnego wymiaru, jaki kształtuje naturę człowieka, a mianowicie jego materialności. Człowiek nie jest bytem czysto duchowym. Jego egzystencja pozostaje zanurzona w przestrzeni i czasie, a on sam zamieszkuje materialny świata, którego jest częścią.

Takie ujęcie jest do pogodzenia z zaproponowanymi przez amerykańskiego teologa głównymi typami teologii obrazu. Ujęcia (B'), (C’) i (D’) sugerują odniesienie do ucieleśnienia. Model funkcjonalny zakłada zdolność przeobrażania materii jako podstawową formę panowania nad nią. Wydaje 
się, że ta zdolność odnosi się do cielesnej natury człowieka, która łączy go z materialnym wymiarem świata. W modelu relacyjnym, szczególnie w jego interpretacji związanej z różnicą płciową, cielesność pozostaje kluczowa. Również i ujęcie wieloaspektowe, szczególnie dzięki swemu syntetycznemu charakterowi, w którym zostają powiązane i wzajemnie odniesione do siebie różne sposoby pojęciowania obrazu, odnosi do cielesności, jako kategorii kluczowej dla boskiego obrazu w człowieku.

Wydaje się, że ujęcie strukturalne może sprawiać w tym względzie większe trudności. Jeśli przyjmiemy, że rozumność i wolność stanowiły dwie uprzywilejowane funkcje człowieka służące do identyfikacji boskiego obrazu w nim, to trzeba stwierdzić, że tradycja klasyczna łączyła je bardziej ze sferą duchową w człowieku niż z jego cielesnością/materialnością. Imago Dei zamieszkiwał w ludzkim duchu. Wystarczy wspomnieć tutaj chociażby Augustyńską teologię obrazu w De Trinitate ${ }^{4}$, która stała się matrycą późniejszych wykładni interesującego nas zagadnienia. Teoria psychologiczna w teologii trynitarnej zakłada, że wiarygodna hermeneutyka Objawionej tajemnicy Boga powinna opierać się na prawdzie o ludzkim byciu na obraz Boga. Obraz ten dostarcza, zachowując wszelkie proporcje, schematy myślowe, które pozwalają na podstawie danych Objawienia mówić sensownie o wewnętrznym życiu Boga. Taki sposób myślenia opiera się na założeniu, że intelekt i wolność stanowią dwa szlachetne akty duchowe ${ }^{5}$. Jako że Bóg jest duchem, istnieje w nim racjonalność i wolność. Podobnie człowiek, stworzony na Jego obraz, jest racjonalny i wolny. Ustanowiona w stworzeniu zależność między duchem nieskończonym a skończonym, która stanowi rdzeń doktryny obrazu, daje możliwość analogicznego wglądu w życie Boga. Zwróćmy uwagę, że powyższy schemat hermeneutyczny, implikuje

4 Na ten temat warto skonfrontować dwa, różniące się podejścia wyrażone w: Kany 2007 oraz Ayres 2010, 297-318. Ciekawą prezentację tematu można znaleźć w: Horn 2014, 479-488; Williams 2014, 178-231.

5 Tomasz z Akwinu, STh., I, q. 27, a. 5, resp.: processiones in divinis accipi non possunt nisi secundum actiones quae in agente manent. Huiusmodi autem actiones in natura intellectuali et divina non sunt nisi duae, scilicet intelligere et velle. Nam sentire, quod etiam videtur esse operatio in sentiente, est extra naturam intellectualem, neque totaliter est remotum a genere actionum quae sunt ad extra; nam sentire perficitur per actionem sensibilis in sensum. Relinquitur igitur quod nulla alia processio possit esse in Deo, nisi verbi et amoris. 
duchową naturę zarówno intelektu, jak i wolności. To sprawiło, że zarówno Augustyn, jak i Tomasz wiązali boski obraz w człowieku z duszą ${ }^{6}$. Przyjęcie takiej perspektywy musiało determinować z konieczności nie tylko twierdzenia o Bogu, lecz także konkretne wersje chrześcijańskiej antropologii. Jak pogodzić takie stanowisko tradycji z przekonaniem współczesnej teologii o tym, że obraz jest rzeczywistością ucieleśnioną?

Do tego trzeba jeszcze dodać, że spośród przedstawionych powyżej możliwości interpretacji obrazu Bożego, co wyraźnie stwierdza Cortez, podejście strukturalne sprawia najwięcej problemów teologiczno-hermeneutycznych. I to z dwóch powodów: po pierwsze, jest ono najmniej udokumentowane biblijnie, po drugie, jak żadne inne, zależy od zmiennych kulturowych, konkretnych kategorii antropologicznych danej epoki. Niemniej jednak trzeba przypomnieć, że to właśnie strukturalne podejście do obrazu było, z historycznego punktu widzenia, dominującym wytłumaczeniem jego istoty, przynajmniej do czasu powstania nowożytnej egzegezy. Wydaje się, że argument z tradycji nie może być traktowany, jako marginalny ${ }^{7}$. Wytłumaczenia strukturalnego nie powinno się arbitralnie odrzucać. Wydaje się, że jest ono implicite istotnie związane z modelami funkcjonalnym i relacyjnym, tym samym musi być bliskie rozwiązaniu wieloaspektowemu. Doświadczenie uczy, że w istocie rzeczy panowanie nad stworzeniem w imieniu Boga oraz intersubiektywność ludzka wymagają zarówno racjonalności, jak i wolności. Pozostaje jedynie problem możliwości ich ujęcia w kategoriach cielesności.

W tym względzie z pomocą przychodzą nam współczesne neuronauki (w wielu swoich odsłonach, szczególnie neuronauka poznawcza) oraz kognitywistyka i wyznaczane przez nich ogólne trendy myślenia o człowieku. $\mathrm{Z}$ ich perspektywy nie ulega wątpliwości, że procesy myślowe i wolność (zdolność podejmowania decyzji) zakorzenione są w biologicznej strukturze człowieka. Istota ludzka stanowi pewnego rodzaju całość, złożoną z wielu części, które wzajemnie na siebie wpływają (i w tym znaczeniu

Zob. de Margeri 1997, 409-410; McFarland 2011, 502-503.

7 Zauważmy ponadto, że krytyka, jaką Cortez wytacza pod adresem ujęcia strukturalnego, zakorzeniona jest głęboko w jego własnej tradycji teologicznej. 
siebie determinują). Biologiczne podłoże wyższych procesów duchowych wydaje się dzisiaj rzeczywistością niepodważalną. Współczesne, wielokierunkowe badania nad funkcjonowaniem mózgu dają odpowiedzi na coraz większą liczbę konkretnych pytań o człowieka i właściwe mu działania. Twierdzenie o biologicznym podłożu procesów myślowych musi determinować również rozumienie struktury boskiego obrazu, który jest rzeczywistością duchowo-materialną. Cielesność człowieka, jego materialność, stanowią istotny składnik jego tożsamości jako boskiego obrazu (Sanna 2006, 317-355; Kupczak 2006, 219-223; Pröpper 2011, 195-224). Imago jest istotnie związany z cielesnością/materialnością, jego siedzibą jest ciało, a on sam jest obrazem materialnym niematerialnej Trójcy.

\section{Imago Dei między redukcjami: kauzalną, ontologiczną i teologiczną}

Podejście tu reprezentowane może wzbudzić pewne wątpliwości. Czy nie jest ono jednak zbyt redukcjonistyczne? Czy nie zdradza istotnych danych tradycji? W tym względzie interesujące dla naszego tematu wydają się wyniki badań interdyscyplinarnych Leonardo Parisa na temat wolności. Uwzględniając dane neuronauk, filozofii i teologii, dochodzi on do przekonania, że „podejście materialistyczne, jeśli dobrze interpretowane, może stanowić korzyść dla chrześcijańskiego przepowiadania, a nie jego granice” (Paris 2012, 353). „Pokusa naturalizacji ludzkiej wolności - stwierdza Paris - może być widziana jako ruch, który nie zagraża relacji bosko-ludzkiej, ale odwrotnie, podtrzymuje ją" (Paris 2012, 22). Obydwie wypowiedzi opierają się na założeniu, wedle którego „twierdzić, iż człowiek jest jedynie materią, może być sposobem powiedzenia, że jest on, i eschatologicznie pozostaje, tylko stworzeniem. Różne antropologie, jedno-, dwu- czy trzyczęściowe są tym samym kompatybilne z chrześcijańskim przesłaniem” (Paris 2012, 352). Konkluzje Parisa są dla nas ważne, ponieważ traktując o wolności, dotykają implicite rzeczywistości obrazu. Skomplikowane i szeroko zakrojone badania, jakie Paris prezentuje w swojej monografii, pozwalają potwierdzić podstawową intuicję dotyczącą materialnego charakteru ludzkiego bycia na 
obraz Trójcy w aspekcie wolności, czyli rzeczywistości istotnej dla rozumienia obrazu. Myślenie Parisa otwiera jednak pewną panoramę poznawczą, która jest aplikowalna również i do ludzkiej racjonalności. To wszystko potwierdza możliwość ujęcia obrazu Bożego w człowieku w kategoriach cielesności i materialności.

Nie jest moim zamiarem wykazanie, że tradycja pomyliła się, twierdząc, iż rozumność i wolność są aktami duchowymi, ani twierdzenie, iż istnieje jedynie to, co materialne, lecz jedynie wskazanie, że relacja, jaka zachodzi między tym, co materialne i duchowe, daleko przekracza jakiekolwiek wytłumaczenie dualistyczne. Takie ujęcie, zgodnie z tym, co stwierdzono w paragrafie pierwszym, jest jak najbardziej zgodne z danymi tradycji, wyjaśnia problemy, które wyjaśniały poprzednie rozwiązania i modele oraz pogłębia rozumienie rzeczywistości w kontekście współczesnego stanu wiedzy. Poza tym, skrajny i uproszczony dualizm ontologiczny nie jest dzisiaj przyjmowany w zasadzie w żadnej z perspektyw: nie podtrzymuje go wizja naukowa ani filozoficzna, ani teologiczna. Oczywiście, jak pokazuje najnowsza historia badań w dziedzinie mind-body, również i monizm nie radzi sobie z fundamentalnymi pytaniami stawianymi przez nauki i humanistykę, dopuszczając się niejednokrotnie nieuprawnionych redukcji, które wykraczają daleko poza kompetencje metodologiczne i przedmiotowe poszczególnych nauk (Bremer 2010; Dirscherl 2012, 439-442). Potrzeba stanowiska, które zdolne byłoby mediować między dualizmem a monistycznym materializmem (szczególnie w jego radykalnej wersji, por. Kessler 2009, 81-115) i jednocześnie było sensowne z punktu widzenia tradycji teologicznej. Najsłuszniejszą opcją wydaje się umiarkowany monizm postulowany ostatnio, na różne sposoby i z różnych perspektyw, zarówno przez naukowców, filozofów, jak i teologów (Green, 2011, 481-482; Lüke 2012, 484-487).

Wspomniana mediacja, pośredni charakter umiarkowanego monizmu, opiera się, między innymi na rozróżnieniu typów redukcji ${ }^{8}$, jakie przyjmuje Searle w swojej propozycji naturalizmu biologicznego. Amerykański filozof

8 Na temat zagadnienia redukcji widzianej z perspektywy teologii, zob. Lüke 2007, 27-30. W ujęciu interdyscyplinarnym temat został opracowany w: tenże 2007. 
buduje swoją teorię umysłu na rozróżnieniu dwóch zasadniczych postaci redukcji: kauzalnej i ontologicznej (Searle 2006). Zgodnie z wyjaśnieniem Searle'a, redukcja kauzalna nie implikuje redukcji ontologicznej, co oznacza w przypadku problemu mind-body, że świadomość jednocześnie jest redukowalna i nieredukowalna do procesów neurobiologicznych. Świadomość może być, zdaniem Searle’a wytłumaczona przez procesy neurobiologiczne, bez których nie istnieje (redukcja kauzalna), chociaż nie może być do nich sprowadzona ontologicznie (redukcja ontologiczna), gdyż perspektywa ontologii pierwszoosobowej nie może być zredukowana do przedmiotowego ujęcia trzecioosobowego zakładającego iluzoryczną naturę subiektywnych stanów świadomościowych (Searle 1999, 49-87) .

Uważam, że analizowane problemy nie pozostają obojętne w stosun$\mathrm{ku}$ do zagadnienia materialnego charakteru obrazu Bożego w człowieku rozumianego syntetycznie z uwzględnieniem wszystkich czterech ujęć przytoczonych w pierwszym paragrafie. Posługując się teoretycznym rozwiązaniem Searle’a i ekstrapolując go na interesujący nas problem, można stwierdzić, że jeśli nasze ujęcie ryzykuje jakąkolwiek formę redukcjonizmu, to nie jest to redukcjonizm ontologiczny. Imago Dei w swoich istotowych funkcjach (rozumność, wolność, relacyjność, zdolność panowania etc.) może być zredukowany przyczynowo do swojego materialnego podłoża bez jednoczesnej redukcji ontologicznej do nich. Choć imago pozostaje zakorzeniony w materialnej strukturze ludzkiego bytu, stanowi zawsze coś więcej niżli tylko ona ${ }^{10}$. Owo więcej można identyfikować jako relację człowieka do Boga, ustanowioną w sposób wolny przez Stwórcę w samym akcie stwórczym. Imago jest osadzony na mocy tego aktu w biologiczno-materialnej, cielesnej naturze człowieka. Jednocześnie, referencyjna natura obrazu od strony teologicznej jest nieredukowalna do substratu materialnego, chociaż przyczynowo (fizycznie) może być do niego redukowana i przezeń wyjaśniana.

W tym miejscu, należy dokonać jeszcze jednego rozróżnienia, które nie interesuje już samych nauk ścisłych, z powodu ich oczywistych za-

9 Krytyczną analizę poglądów Searle’a można znaleźć w: Nida-Rümelin 2002, 205-221.

10 Por. główny argument monografii Murphy 2006. 
łożeń przedmiotowo-metodologicznych, ale jest istotne dla ujęcia teologicznego. Chodzi o rozróżnienie redukcji kauzalnej natury fizykalnej od redukcji kauzalnej natury teologicznej (akt stwórczy). Posługując się schematem klasycznej metafizyki, można stwierdzić, że fizykalna redukcja przyczynowa odnosi się do drugiego rzędu przyczyn i, teologicznie, zakłada działanie przyczyny pierwszej. Bez przyjęcia takiego założenia, można by odnieść wrażenie, że materia istnieje sama z siebie. Redukcja kauzalna do struktur biologicznych nie wyklucza (i sama z siebie nie zakłada) teologicznej redukcji kazualnej wyrażonej w doktrynie stworzenia, ani na odwrót. Właśnie to rozróżnienie pozwala nam uchwycić, że obraz, w swojej materialnej strukturze, pozostaje czymś więcej niż suma wszystkich jego biologiczno-materialnych substratów, ponieważ ukierunkowany jest na mocy wolnej decyzji Stwórcy ku relacji z Nim. Jako taki, imago Dei, na mocy aktu stwórczego jest materialnym obrazem Niematerialnej Trójcy. Materialność obrazu nie może (sic!) wykluczać jego stworzonej natury, ale wręcz ją teologicznie potwierdza. Na potwierdzeniu tym, któremu nie sposób zaprzeczyć naukowo, którego naukowo nie można ani dowodzić, ani zakładać, opiera się fakt nieredukowalności boskiego obrazu do struktur materialnych. Jego początkiem, pierwszą przyczyną i punktem odniesienia jest Trójjedyny Bóg. Teologicznie imago może być wyjaśniony w całej swojej egzystencjalnej pełni dopiero poprzez redukcję kauzalną do boskiego, wolnego i bezinteresownego samoudzielenia stworzeniu, które ustanawia człowieka jako swoją własną reprezentację i, jako takiego, powołuje go do udziału we własnym życiu. Obraz boski w człowieku, przy zachowaniu całej swojej materialnej struktury wyjaśnianej w filozoficznym binomium Searle’a, zostaje ujęty w perspektywie teologicznej jedynie wtedy, kiedy może być zredukowany do trynitarnego działania stwórczego, jako swojej pierwszorzędnej i ostatecznej przyczyny kauzalnej. Waga tego teologicznego stwierdzenia dotyczy nie tylko protologii, lecz także eschatologii, informuje nie tylko o początkach ludzkiej tożsamości, lecz także o ostatecznym powołaniu człowieka. Człowiek jest obrazem Boga, gdyż w całym swoim materialnym istnieniu, na mocy stwórczej woli Boga, ustanowiony jest jako odsłonięcie gramatyki boskiego bycia w świecie i powołany do 
pełnego w nim udziału w przyszłości. Ludzkie bycie na obraz jest stworzonym wyrazem wyjątkowości bosko-ludzkiej relacji, którą nazywamy stworzeniem. Człowiek i jego konkretne istnienie, ujęte logicznie pomiędzy swoim początkiem w Bogu (Bóg jako przyczyna sprawcza) a swoim w nim spełnieniu (Bóg jako przyczyna celowa), jest dynamicznym obrazem Stwórcy w świecie. Człowiek jest obrazem Trójcy nie dlatego, że jest bytem materialnym, lecz właśnie dlatego, iż Bóg ustanawia go w jego materialnym istnieniu jako byt w szczególnej relacji do samego siebie ${ }^{11}$. Tym samym jego pełna definicja jako bytu materialnego może być osiągnięta tylko wtedy, gdy przyjmuje się redukcję teologiczną. To ona jednocześnie ujmuje człowieka jako byt materialny, ale i jednocześnie nie pozwala na jego redukcję jedynie do materii.

Zaproponowana koncepcja ucieleśnionego obrazu, jeśli odpowiednio ujęta, nie zakłada radykalnego monizmu ontologicznego, który następnie wykluczałby redukcję teologiczną. Nie wyklucza ona istnienia transcendentnego pierwiastka w człowieku, jego wymiaru duchowego, utrzymuje jednak, że stanowi on nierozdzielną całość z jego cielesnością. Opisy naukowe wyjaśniają strukturę i funkcjonowanie boskiego obrazu w jego materialnym wymiarze. Poza granicami ich kompetencji pozostaje jednak przestrzeń teologicznie ujmowanej relacji do Boga, która zakorzeniona jest - po stronie stworzenia - w materialności człowieka, w jego cieleśnie osadzonych rozumności i wolności pozwalających mu na wchodzenie $\mathrm{w}$ wielowymiarowe relacje i panowanie nad stworzonym światem. Okazuje się, że nie trzeba przyjmować dwóch oddzielnych substancji (duchowej i materialnej), aby utrzymać główne punkty tradycyjnej nauki katolickiej ${ }^{12}$.

11 Zastosowana tu hermeneutyka obrazu Bożego może zostać odniesiona do propozycji nowej interpretacji rzeczywistości duszy zaproponowanej przez J. Ratzingera. Zob. teksty w: Ratzinger 2014.

12 Koncepcja ta, wskazując na organiczność, wewnętrzność obu wymiarów istnienia (duchowego i materialnego), uchodzić może za niedualistyczną próbę wyrażenia intuicji klasycznego hylemorfizmu w horyzoncie nowoczesnego, naukowego rozumienia świata. Na temat hylemorfizmu wyczerpująco informuje Bremer 2010, 38-45. 


\section{Podsumowujące uwagi metodologiczne}

Przedstawione treści skłaniają do rozważań natury metodologicznej. Jako podsumowanie i syntezę wcześniejszych danych proponuję następujące punkty.

Po pierwsze, teologia obrazu Bożego w człowieku, jaką zaproponowano powyżej, opera się na założeniu, że całościowe jego ujęcie, także od strony teologicznej, domaga się jego poszerzenia o wymiar materialno-cielesny. Fundamentalna materialność obrazu jest do pogodzenia ze wszystkimi tradycyjnymi ujęciami jego istoty, jakie w ciągu wieków wypracowała teologia chrześcijańska. Dotyczy to nawet modelu strukturalnego, który wiązał imago z myśleniem i wolnością, te zaś ujmował w ich powiązaniu z duchem. W świetle najnowszych badań naukowych, zarówno racjonalność, jak i wolność związane są z biologicznym, neurologicznym substratem bycia człowiekiem. To skłania do powiązania rzeczywistości obrazu z „materialnym” wymiarem ludzkiego bycia. Zaproponowany powyżej argument opiera się na założeniu, że istnieje organiczny związek między tym, co materialne, a tym, co duchowe w człowieku. Uznanie racjonalności i wolności (istotnych składników ludzkiego bycia na obraz Boga) za istotnie powiązane z układem nerwowym nie musi jednak oznaczać redukcji samego obrazu tylko do struktur materialnych. Treściowa zawartość teologicznej idei obrazu oznacza, że człowiek jako taki, to znaczy jako byt materialny, może być w pełni zrozumiany jedynie wtedy, kiedy ujmuje się go w jego organicznej relacji z Bogiem. Redukcja do tego, co biologiczne i materialne nie może wyjaśnić człowieka na wszystkich znanych poziomach jego faktycznego istnienia. Tym samym jednak nie trzeba utrzymywać faktu istnienia jakiejś różnej, oddzielonej rzeczywistości (substancji) duchowej w człowieku. Imago Dei identyfikuje człowieka w jego cielesności/materialności jako byt w szczególnej relacji do Boga. Jako taki stanowi pierwotny kontekst wszelkiej teologicznej nauki o człowieku i jako taki, sam w sobie (jako koncepcja teologiczna) nie podlega kontestacji z perspektywy nauk szczegółowych. Teologia może (i powinna) korzystać ze zdobyczy nauk, te zaś mogą w teologii odnaleźć szerszą perspektywę swoich rozważań już poza własnym przedmiotem, metodą i porządkiem badawczym. 
Po drugie, chrześcijańskie ujęcie właściwej dla niego nauki o stworzeniu wymaga utrzymania balansu i symultaniczności między trzema zaproponowanymi redukcjami: ontologiczną, i obydwoma kauzalnymi. Tak jak redukcja kauzalna (redukcja do materialnych komponentów warunkujących poszczególne aktywności umysłu) może współistnieć z nieredukowalnością ontologiczną, podobnie może ona współistnieć z teologiczną redukcją kauzalną (do aktu stworzenia ustanawiającego fundamentalną referencyjność obrazu). Z punktu widzenia teologii, przyjęcie trzeciej redukcji (kauzalnej pierwszorzędnej) umożliwia teologiczną akceptację fizykalnej redukcji kauzalnej. W praktyce oznacza to, że redukcja zjawisk i rzeczy do ich substratu materialnego (neurobiologicznego) nie powinna rościć pretensji do wyczerpującego ich opisu i wyjaśnienia. Pierwszorzędne wyjaśnienie kauzalne nie wyjaśnia wszystkiego. Człowiek pozostaje czymś więcej niż li tylko sumą swoich części składowych i fakultetów (nieredukowalność ontologiczna), również i dlatego, że jego istnienie na mocy aktu stwórczego ukierunkowane jest ku samemu Bogu (redukcja kauzalna do przyczyny pierwszej). Innymi słowy, właściwie ujęta nauka o stworzeniu wymaga umiejętnego połączenia redukcji kauzalnej z nieredukowalnością ontologiczną (jak u Searle’a) oraz przyjęcia niesprzecznej z nimi redukcji kauzalnej pierwszego rzędu (teologicznej). To oczywiście implikuje niewystarczalność redukcji kauzalnej do materialnego substratu. Para: 'fizykalna redukcja kauzalna' i 'ontologiczna nieredukowalność' nie wyjaśniają wszystkiego. Fenomen człowieka wykracza poza to, co o nim stwierdza przytoczone binomium. Bez nauki o stworzeniu wyjaśnienie, jakie oferują, choć adekwatne w przestrzeni ich własnej metody, pozostaje nieusuwalnie jednowymiarowe. Poszerzenie wyjaśnienia interesującego nas fenomenu człowieka o redukcję teologiczną, ujawniającą w substracie materialnym strukturę obrazu, sprawia, że paradygmat dualistyczny zostaje przekroczony również i w teologii.

Po trzecie, w związki z przedstawioną powyżej argumentacją za cielesnością/materialnością boskiego obrazu w człowieku, potrzeba postawić postulat badawczy nowego opracowania przez teologię pojęcia materii. Powyższe rozważania zaprezentowały nową wizję relacji materii i ducha, w której sta- 
nowią one rozróżnioną jedność. Dane tradycji na temat ich relacji muszą zostać gruntowanie przemyślane. Duchowości człowieka nie należy zbyt szybko odłączać od substratu materialnego. Podobnie, teologiczne rozumienie materii nie może być ograniczone do dialektycznej relacji z duchowością. Nie można już dłużej utrzymywać, że materią jest to, co nie jest duchem i vice versa. Obecny stan wiedzy domaga się pogłębionej koncepcji materii, która zdolna byłaby przekroczyć zarówno mielizny dialektycznego dualizmu, jak i totalizującego monizmu ontologicznego. W tym względzie trzeba stwierdzić, że teologia nie wypracowała dotychczas jakiejś pogłębionej konceptualizacji rzeczywistości materii. Szczątki i zarysy takiej teorii pojawiały się w epokach, kiedy dyskutowano różne wymiary tajemnicy Wcielenia, od pierwszych sporów z doketyckimi wersjami gnozy aż do refutacji ikonoklazmu. Zasadniczym pytaniem teologii materii jest to, które tematyzuje jej odniesienie do Boga: dlaczego Trójjedyny Stwórca stwarza materię? Jakie jest jej miejsce w historii świętej? Odpowiedzi gnostyckie, podkreślające nieboskie pochodzenie materii mającej być jedynie efektem upadku, zostały odrzucone jako nieadekwatne ujęcia chrześcijańskiej teologii stworzenia już w teologii pierwotnych wspólnot. Stworzenie materialnego świata jest wyrazem woli Boga (Williams 2014, 291), a sama materialność stworzenia zajmuje istotne miejsce w Jego stwórczym planie. $\mathrm{W}$ tej perspektywie pozostaje myśleć o materialności właściwej stworzonemu światu jako części boskiego objawienia, jako sposobie boskiego podarowania się stworzeniu. Interesująca nas materialność, w całej swojej dynamicznej, ewoluującej plastyczności, jest okazją do odsłonięcia pewnych aspektów boskiego życia. To wszystko nie pozostaje obojętne dla relacji nauki i wiary. Przyjmując, że nauki zajmują się materialnym wymiarem świata, trzeba stwierdzić, iż ów przedmiot ich podstawowego zainteresowania nie pozostaje obcy i obojętny refleksji teologicznej. Oczywiście poznanie nauk i poznanie teologiczne zajmują się różnymi wymiarami materialnego świata: nauki badają naturę, strukturę i pochodzenie materii, podczas gdy teologia rozważa ją pod kątem jej stworzoności włączającej ją w historię świętą spotkania Boga i człowieka. Podwojona perspektywa oglądu tej samej rzeczywistości oferuje, moim zdaniem, bardziej całościowe ujęcie faktu istnienia w znanej nam formie. 
Nie powinna tym samym być jedynie tolerowana, ale wręcz uprzednio założona jako - de iure - sposobność głębszego oglądu prawdy rzeczy.

Po czwarte, za wspomnianym już powyżej Parisem, trzeba wyraźnie stwierdzić, że wyjaśnienie teologiczne i wyjaśnienie nauk ścisłych (każdej w granicy własnych kompetencji) mogą być przyjmowane paralelnie i równocześnie. Zdaniem Parisa, nauki i teologia powinny utrzymywać się w napięciu bycia vis-à-vis, nauka w obecności (alla presenza) teologii i teologia w obecności nauk. Taka convivenza ospitale jako metoda interdyscyplinarnego myślenia zmierza nie tyle do zrozumienia tego, co nauka mówi teologii, a teologia nauce, ile przede wszystkim do tego, aby zobaczyć, co teologia mówi o człowieku w obecności nauk, a nauki w obecności teologii. Współpraca nauk i teologii nie musi polegać na poszukiwaniu komplementarności ich wyjaśnień i twierdzeń, lecz na odnalezieniu przestrzeni dialogu, w której obie będą mogły siebie wyrazić i ubogacić (Paris 2012, 353). Takie bycie vis-à-vis domaga się od teologii i od nauk skrupulatnego przestrzegania swoich własnych granic przedmiotowo-metodologicznych, ale także i wzajemnego przysłuchiwania się sobie. Obustronna zamkniętość prowadzi zawsze do nieuprawnionych redukcjonizmów, które zbudowane są na nieadekwatnych estymacjach metodologicznych.

\section{Bibliografia}

Ayres, L. 2010. Augustine and the Trinity. Cambridge: Cambridge University Press. Bremer, J. 2010. Wprowadzenie do filozofii umysłu, (Myśl filozoficzna). Kraków: WAM. Cortez, M. 2010. Theological Anthropology: A Guide for the Perplexed. London-New York: T\&t Clark - Bloomsbury.

Dirscherl, E. 2012. “Leib-Seele Beziehung.” W Neues Lexikon der katholischen Dogmatik, red. W. Beinert, B. Stubenrauch, 439-442. Freiburg-Basel-Wien: Herder. Green, J.B. 2011. "Soul.” W Cambridge Dictionary of Christian Theology, red. I.A. McFarland, D.A.S. Fergusson, K. Kilby, I.R. Torrance, 481-482. Cambridge: Cambridge University Press.

de Margeri, B. 1997. La Trinité chrétienne dans l'histoire. Paris: Beauchesne.

McFarland, I.A. 2011. "Theological Anthropology.” W Cambridge Dictionary of Christian Theology, red. I.A. McFarland, D.A.S. Fergusson, K. Kilby, I.R. Torrance. Cambridge: Cambridge University Press. 
Heller, M., Pabian, T. 2014. Elementy filozofii przyrody. Kraków: Copernicus Center Press,.

Hohol, M. 2013. Wyjaśnić umysł. Struktura teorii neurokognitywnych. Kraków: Copernicus Center Press.

Horn, Ch. 2014. “Anthropologie.” W Augustinus Handbuch, red. V. Henning Drecoll, UTB 4187, 479-488. Mohr Siebeck, Tübingen.

Kany, R. 2007. Augustins Trinitätsdenken: Bilanz, Kritik und Weiterführung der modernen Forschung zu "De trinitate”, (Studien Und Texte Zu Antike Und Christentum / Studies and Texts in Antiquity and Christianity). Tübingen: Mohr Siebeck.

Kessler, H. 2009. Evolution und Schöpfung in neuer Sicht. Kevelaer: Butzon \& Bercke. Kupczak J. 2006. Dar i komunia. Teologia ciała w ujęciu Jana Pawła II. Kraków: Znak. Lüke, U. 2007. Das Säugetier von Gottes Gnaden. Evolution - Bewusstsein - Freiheit. Freiburg-Basel-Wien: Herder.

Lüke, U., (red.). 2007. Der Mensch - nichts als Natur? Interdisziplinäre Annäherungen. Darmstadt: Wissenschaftliche Buchgesellschaft.

Lüke, U. 2012. “Monismus.” W Neues Lexikon der katholischen Dogmatik, red. W. Beinert, B. Stubenrauch, 484-487. Freiburg-Basel-Wien: Herder.

Murphy, N. 2006. Bodies and Souls, or Spirited Bodies?, (Current Issues in Theology). Cambridge: Cambridge University Press.

Newberg, A. B. 2010. Principles of Neurotheology, (Ashgate Science and Religion Series). Aldershot: Ashgate.

Nida-Rümelin, M. 2002. Causal Reduction, Ontological Reduction and First-Person Ontology. Notes on Searle's View about Consciousness, w: G. Grewendorf, G. Meggle (red.), Speech Acts, Mind, and Social Reality. Discussions with J. R. Searle, Kluwer, 205-221.

Paris, L. 2012. Sulla libertà. Prospettive di teologia trinitaria tra neuroscienze e filosofia. Roma: Città Nuova.

Pröpper, T. 2011. Theologische Anthropologie. I. Freiburg-Basel-Wien: Herder.

Ratzinger, J. 2014. Zmartwychwstanie i życie wieczne. Studia o eschatologii i teologii nadziei, (JROO, 10), Lublin: KUL.

Sanna, I. 2006. L'identità aperta. Il cristiano e la questione antropologica, (Biblioteca di Teologia Contemporanea, 132), Brescia: Queriniana.

Searle, J.R. 1999. Umysł na nowo odkryty. Warszawa: PIW.

Searle, J.R. 2006. Umysł. Krótkie wprowadzenie. Warszawa: Rebis.

Souvignier, G., Lüke, U. (red.). 2008. Gottesbilder an der Grenze zwischen Naturwissenschaft und Theologie. Darmstadt: Wissenschaftliche Buchgesellschaft.

Williams, A.N. 2014. Boski zmyst. Intelekt w tradycji patrystycznej. Kraków: WAM. 